\title{
Evaluation of a new sensitive nitrite test as a reliable screening tool for bacteriuria
}

\author{
T RABI
}

From the Division of Natural Products, R\&D Authority, Ben-Gurion University of the Negev, Beer-Sheva, Israel

SUMmARY A new sensitive nitrite test, the SRN test, was evaluated for its suitability as a reliable screening technique for the detection of bacteriuria. The SRN test was compared to a currently available nitrite test, the Microstix nitrite test, and the results obtained with both nitrite tests were assessed in comparison with the results of the quantitative culture method. Of 158 cases of significant bacteriuria found among 1060 randomly collected specimens, the SRN test detected $90 \%$ and the Microstix nitrite test, $30 \%$. The higher reliability of the SRN test reflects its high capability of nitrite detection $(\geqslant 0 \cdot 1 \mathrm{ppm})$, and its ability to overcome interference by various factors, such as dark colour of the urine, presence of phenazopyridine, urobilinogen, blood, high concentration of ascorbate, and high urinary $\mathrm{pH}$, all of which do interfere with the Microstix nitrite test. The high sensitivity of the SRN test allows detection of bacteriuria in urine specimens collected at random throughout the day; the test is therefore not restricted to the use of first-morning samples as are other nitrite tests. Since the SRN test was found to give a quantitative indication of the size of the bacterial population, the possibility of its use as an exact quantitative test under controlled conditions is discussed.

The quantitative urine culture is the most reliable way of diagnosing urinary tract infection (UTI). ${ }^{1}$ However, the high cost, the need for trained personnel, the inconvenience of collecting clean-voided specimens, and especially the need to treat the symptomatic patient immediately limit its routine use in office practice.

A simple screening test for bacteriuria, if rapid, accurate, and inexpensive would be of great advantage in the routine diagnosis of UTI. In addition, the availability of such a test would encourage screening programmes for asymptomatic populations with a high risk of developing UTI, such as pregnant women, ${ }^{2} 3$ diabetics, ${ }^{45}$ children, ${ }^{6}$ premature infants, ${ }^{7}$ and patients with catheterisation of the urinary tract. ${ }^{8}$ A number of rapid screening tests-culture procedures, ${ }^{910}$ chemical tests $^{11}$ and combinations of the two methods $11{ }^{12}$ _have recently become available. Of the chemical methods, the nitrite test appears to be the most commonly used, and it has recently appeared on the market in a variety of forms. ${ }^{13-16}$

The nitrite tests are based on the ability of enteric Gram-negative bacteria, the commonest pathogens of the urinary tract, ${ }^{17}$ to reduce dietary-derived nitrate

Accepted for publication 19 November 1980 in the urine to nitrite. ${ }^{18}$ These tests, however, have often been reported to be inaccurate ${ }^{13} 14$ or unreliable. ${ }^{6} 1516$ 19-21 In this study, we evaluated a new sensitive nitrite test, the SRN test, for its suitability as an efficient screening test for detecting bacteriuria. Our study was thus designed to investigate the reliability and sensitivity of the test and the effect of various factors known to interfere with the accuracy of nitrite tests. 121422 The results obtained with the SRN test for a series of randomly collected urine specimens were compared with those given by a commonly used nitrite test, the Microstix nitrite test. The quantitative culture method was used as the control. Factors which can affect the accuracy of the SRN test as a technique for detecting bacteriuria, both qualitatively and quantitatively, are discussed.

\section{Material and methods}

URINE SPECIMENS

Urine specimens were collected at random from a general population of patients attending one of the health centres of the "Sick Fund of the General Labor Federation." The samples were supplied to us by the bacteriology laboratory of this health centre. Each urine specimen was first tested for nitrite and 
then plated for culture (control). The $\mathrm{pH}$ and the nitrate concentration of each urine sample were also recorded.

\section{NITRITE TESTS}

Urine specimens were tested quantitatively for nitrite by the SRN test (Advanced Products, BeerSheva Ltd). The tests were carried out in two series of experiments: series I (443 specimens) was conducted in 1977 and series II (617 specimens) in 1978 (Table 1). In the presence of nitrite, a characteristic pink-violet colour develops, its intensity being proportional to the nitrite concentration. The quantitative determination of the nitrite content of each sample was carried out visually by comparison with a standard colour chart supplied with the test.

For purposes of comparison, the urine samples were also tested for nitrite by the nitrite pad area of the Microstix test (Ames Co, Division of Miles Laboratories, Stoke Poges, England), thereafter referred to as the "Microstix test." According to package instructions the test is not quantitative, and any shade of pink appearing in the nitrite pad of the Microstix, was taken as a positive result.

The sensitivities of the SRN and Microstix tests were also compared as follows: urine samples, obtained from healthy men, to which increasing amounts of nitrites had been added were tested with both nitrite tests. The tests were carried out on both light and dark coloured urine so that the effect of the natural colour of the urine on the detection ability of the tests could be evaluated.

Possible interference factors 121422 which may be present in the urine were tested for their effect on the SRN test: nitrite-free urine samples with macroscopic haematuria or containing phenazopyridine, bilirubin, abnormally high concentration of urobilinogen $(4-12 \mathrm{mg} / \mathrm{dl})$, or ascorbic acid (10-100 $\mathrm{mg} / \mathrm{dl}$ ), to which nitrite had been added were tested with the SRN test, and its detection limit was determined.

The effect of urinary $\mathrm{pH}$ on the sensitivity of both nitrite tests was studied in nitrite-free urine specimens, obtained from healthy persons. These specimens had been adjusted to various $\mathrm{pH}$ levels ranging from 4 to 9 . Various amounts of nitrite were added to each sample and the detection limits of the SRN and Microstix tests were determined.

\section{URINE CULTURES}

The conventional urine culture was used as the reference method. A $0 \cdot 1 \mathrm{ml}$ sample of each original specimen and $0.1 \mathrm{ml}$ aliquots of serial dilutions of the specimen in sterile saline were plated on MacConkey's agar. Colonies were counted after an overnight incubation at $37^{\circ} \mathrm{C}$. Urine specimens with $\geqslant 10^{5}$ bacteria $/ \mathrm{ml}$ were considered as showing significant bacteriuria. ${ }^{23}$ Pathogens in the bacteriuric. specimens were identified as a routine procedure bs the Central Laboratory of the General Labof Federation Clinic.

URINARY NITRATE

Urinary nitrate was determined quantitatively by the Szechrome NAS method:24 a $0.5 \mathrm{ml}$ urine sample (containing 2 to $20 \mathrm{ppm} \mathrm{NO}_{3}{ }^{-}$) was mixed with $5 \mathrm{mb}$ of the NAS reagent. The violet colour which develops is stable for at least an hour and the nitrate conw centration is determined colorimetrically ( $\lambda \max 57 \%$ $\mathrm{nm})$.

URINARY pH

The $\mathrm{pH}$ of the urine was determined with a PHM 6ख్ standard $\mathrm{pH}$ meter.

\section{Results}

Of the 158 samples with significant bacteriuria 143 cases were detected with the SRN test (sensitivity ofo $90 \%$ ), whereas only 50 cases were discerned by the Microstix test (sensitivity of 26 to $34 \%$ ). The specifo city of the SRN test was 99.3-99.5\% (three false positives-that is, positive nitrite assay in urine with $<10^{5}$ bacteria $/ \mathrm{ml}$ - in each of the series) as opposeô to $99.9 \%$ for the Microstix test. The nitrite test waQ consistently negative at bacterial concentration $\overrightarrow{8}$ $<10^{5}$ bacteria/ml.

Ninety-seven per cent of the bacteriuric cases were caused by enteric Gram-negative bacilli-that i\$, nitrate-reducing organisms (Table 2). The ability of the SRN test to detect bacteriuria in these cases was higher than that of the Microstix both for 1 bacteria/ml and for higher bacterial concentrations. irrespective of the bacterial species. Three per cent of the bacteriuric specimens in the study containeg Gram-positive cocci; this figure is in keeping wit that usually found in the general population. ${ }^{17}$ these cases, bacteriuria was not discerned by eithe of the two nitrite tests, since these organisms do not reduce nitrate. ${ }^{25}$

The relation between the frequency of fals? negatives in the nitrate-reducing bacteriuric specis mens and the size of bacterial population (Table shows that with the SRN test false-negatives wefe found only at the threshold concentration significant bacteriuria. At higher bacterial concentrations the SRN test did not "miss" any case gf bacteriuria. The Microstix test, however, did nôt discern any of the bacteriuric cases with $10^{5}$ bacteri $\mathrm{ml}$ and failed to detect some cases at the higher bacterial concentrations, even at $\geqslant 10^{9}$ bacteria/m.

The sensitivities of the SRN and Microstix tesps 
Table 1 Ability of SRN test and Microstix test to detect significant bacteriuria in random urine specimens

\begin{tabular}{|c|c|c|c|c|c|c|c|c|c|c|c|}
\hline & \multirow{3}{*}{$\begin{array}{l}\text { Total no of } \\
\text { specimens }\end{array}$} & \multicolumn{5}{|c|}{ Significant bacteriuria } & \multicolumn{5}{|c|}{ Non-significant bacteriuria } \\
\hline & & \multirow{2}{*}{$\begin{array}{l}\text { No of speci- } \\
\text { mens with } \\
\geqslant 10^{s} \\
\text { bact } / \mathrm{ml}^{*}\end{array}$} & \multicolumn{4}{|c|}{ Nitrite test positive } & \multirow{2}{*}{$\begin{array}{l}\text { No of speci- } \\
\text { mens with } \\
<10^{5} \\
\text { bact/ml* }\end{array}$} & \multicolumn{4}{|c|}{ Nitrite test positive } \\
\hline & & & $\begin{array}{l}\text { SRN } \\
\text { test }\end{array}$ & $\begin{array}{l}\% \\
\text { sensitivity } \dagger\end{array}$ & $\begin{array}{l}\text { Microstix } \\
\text { test } \ddagger\end{array}$ & $\begin{array}{l}\% \\
\text { sensitivity } \dagger\end{array}$ & & $\begin{array}{l}\text { SRN } \\
\text { test }\end{array}$ & $\begin{array}{l}\% \\
\text { specificity } \S\end{array}$ & $\begin{array}{l}\text { Microstix } \\
\text { test }+\end{array}$ & $\begin{array}{l}\% \\
\text { specificity§ }\end{array}$ \\
\hline $\begin{array}{l}\text { Series I } \\
\text { Series II }\end{array}$ & $\begin{array}{l}443 \\
617\end{array}$ & $\begin{array}{r}50 \\
108\end{array}$ & $\begin{array}{l}45 \\
98\end{array}$ & $\begin{array}{l}90 \\
91\end{array}$ & $\begin{array}{l}13 \\
37\end{array}$ & $\begin{array}{l}26 \\
34\end{array}$ & $\begin{array}{l}393 \\
509\end{array}$ & $\begin{array}{l}3 \\
3\end{array}$ & $\begin{array}{l}99 \cdot 3 \\
99 \cdot 5\end{array}$ & $\begin{array}{l}1 \\
1\end{array}$ & $\begin{array}{l}99 \cdot 9 . \\
99 \cdot 9\end{array}$ \\
\hline
\end{tabular}

*Culture method.

$\dagger \%$ sensitivity $=\frac{\text { test positive, infected }}{\text { total infected }} \times 100$.

$\ddagger$ Nitrite pad area of Microstix.

$\S \%$ specificity $=\frac{\text { test negative, not infected }}{\text { total not infected }} \times 100$.

Table 2 Dependence of reactions of SRN and Microstix tests on bacterial species and bacterial concentrations in randomly collected bacteriuric specimens

\begin{tabular}{|c|c|c|c|c|c|}
\hline \multirow[t]{2}{*}{ Organism } & \multirow[t]{2}{*}{ Total no of bacteriuric specimens } & \multirow[t]{2}{*}{ Bacteria $/ m^{*}$} & \multirow[t]{2}{*}{ No of specimens } & \multicolumn{2}{|c|}{ No detected by nitrite test } \\
\hline & & & & SRN test & Microstix test \\
\hline E coli & 132 & $\begin{array}{r}10^{5} \\
>10^{5}\end{array}$ & $\begin{array}{l}35 \\
97\end{array}$ & $\begin{array}{l}24(66 \%) \\
97(100 \%)\end{array}$ & $\begin{array}{c}0(0 \%) \\
37(30 \%)\end{array}$ \\
\hline Proteus spp & 12 & $\begin{array}{r}10^{5} \\
>10^{5}\end{array}$ & $\begin{array}{l}6 \\
6\end{array}$ & $\begin{array}{l}4 \\
6\end{array}$ & $\begin{array}{l}\mathbf{0} \\
\mathbf{0}\end{array}$ \\
\hline Klebsiella spp & 8 & $\begin{array}{r}10^{5} \\
>\quad 10^{5}\end{array}$ & $\begin{array}{l}4 \\
4\end{array}$ & $\begin{array}{l}2 \\
4\end{array}$ & $\begin{array}{l}\mathbf{0} \\
\mathbf{3}\end{array}$ \\
\hline Enterobacter spp & 4 & $\begin{array}{r}10^{5} \\
>10^{5}\end{array}$ & $\begin{array}{l}1 \\
3\end{array}$ & $\begin{array}{l}\mathbf{0} \\
\mathbf{3}\end{array}$ & $\begin{array}{l}0 \\
2\end{array}$ \\
\hline Pseudomonas spp & 2 & $\begin{array}{r}10^{5} \\
>10^{5}\end{array}$ & $\begin{array}{l}1 \\
1\end{array}$ & $\begin{array}{l}1 \\
1\end{array}$ & $\begin{array}{l}\mathbf{0} \\
\mathbf{0}\end{array}$ \\
\hline Streptococcus spp & 5 & $\geqslant 10^{5}$ & 5 & 0 & $\mathbf{0}$ \\
\hline
\end{tabular}

Bacterial concentration is given only in orders of magnitude.

*Culture method.

Table 3 Ability of the SRN and Microstix tests to detect significant bacteriuria in random urine specimens with various concentrations of nitrate-reducing bacteria

\begin{tabular}{|c|c|c|c|c|c|c|}
\hline & & \multicolumn{5}{|c|}{ Bacterial concentration per $m l$} \\
\hline & & $10^{5}$ & $10^{6}$ & $10^{7}$ & $10^{8}$ & $\geqslant 10^{\circ}$ \\
\hline \multirow[t]{3}{*}{ Series I } & No of bacteriuric samples* & 20 & 1 & 11 & 8 & 10 \\
\hline & No detected-SRN test & 15 & 1 & 11 & 8 & 10 \\
\hline & No detected-Microstix & 0 & 1 & 6 & 3 & 3 \\
\hline \multirow[t]{3}{*}{ Series II } & No of bacteriuric samples* & 30 & 17 & 40 & 13 & 8 \\
\hline & No detected-SRN test & 20 & 17 & 40 & 13 & 8 \\
\hline & No detected-Microstix & 0 & 6 & 23 & 5 & 3 \\
\hline
\end{tabular}

Bacterial concentration is given only in orders of magnitude.

Microstix = nitrite pad of Microstix test.

*Culture method.

were also compared in an experimental system, as described above. Table 4 presents the colour intensities obtained with the SRN test and Microstix test in both light and dark nitrite-free urine with increasing amounts of added nitrites. It can be seen that the threshold level of SRN test is at least 40 times lower than that of the Microstix test. Furthermore, whereas the SRN test is not affected by the colour of the urine, natural urine colour does interfere with the Microstix test, which is less sensitive in darker urine samples.
An orange colour, present in the urine of patients treated with phenazopyridine does not interfere with the SRN test, but does affect the Microstix test as was also reported by Craig ${ }^{11}$ and Moffat. ${ }^{12}$ In six orangecoloured urine samples obtained from bacteriuric patients treated with phenazopyridine, concentrations of nitrites ranging from 1 to $20 \mathrm{ppm}$ were detected by the SRN test. On the other hand, the Microstix test failed to detect nitrites in any of these bacteriuric specimens. Tests performed with both nitrite tests on bacteria-free urine coloured orange by 
Table 4 Colour intensities of SRN and Microstix tests in light-and dark-coloured urine samples to which increasing amounts of nitrite had been added

\begin{tabular}{|c|c|c|c|c|c|c|c|}
\hline \multirow[t]{3}{*}{ Nitrite concentration (ppm) } & \multicolumn{3}{|c|}{ SRN test } & \multicolumn{4}{|c|}{ Microstix test } \\
\hline & \multicolumn{3}{|c|}{ Light and dark urines $(n=31)$} & \multicolumn{2}{|c|}{ Light urine $(n=14)$} & \multicolumn{2}{|c|}{ Dark urine $(n=17)$} \\
\hline & \multicolumn{2}{|c|}{ Colour } & No of positives & Colour & No of positives & Colour & No of positives \\
\hline 0.1 & \multirow{2}{*}{\multicolumn{2}{|c|}{$\begin{array}{l}\text { pale pink } \\
\text { pink }\end{array}$}} & 31 & - & - & - & - \\
\hline 0.5 & & & 31 & - & - & - & - \\
\hline 1 & \multicolumn{2}{|c|}{ dark pink } & 31 & - & - & - & - \\
\hline 2 & \multicolumn{2}{|c|}{ light violet } & 31 & - & - & - & - \\
\hline 4 & \multicolumn{2}{|c|}{ violet } & 31 & pale pink & 4 & - & - \\
\hline 6 & \multicolumn{2}{|c|}{ violet } & 31 & pink & 9 & - & - \\
\hline 8 & \multirow{2}{*}{\multicolumn{2}{|c|}{$\begin{array}{l}\text { dark violet } \\
\text { dark violet }\end{array}$}} & 31 & , & 12 & - & - \\
\hline 10 & & & 31 & " & 13 & pale pink & 5 \\
\hline 15 & \multicolumn{2}{|c|}{ reddish violet } & 31 & $"$ & 13 & pink & 9 \\
\hline 20 & , & , & 31 & ," & 13 & " & 12 \\
\hline 30 & , & , & 31 & , & 14 & „, & 15 \\
\hline 40 & ", & $"$ & 31 & ", & 14 & ," & 15 \\
\hline 50 & " & $"$ & 31 & $"$ & 14 & 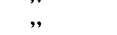 & 16 \\
\hline 60 & " & " & 31 & ", & 14 & ” & 17 \\
\hline
\end{tabular}

phenazopyridine, to which increasing amounts of nitrite had been added, showed that even concentrations as high as $40 \mathrm{ppm}$ of nitrite could not be discerned by the Microstix test, as the pinkish orange colour obtained with these samples was almost indistinguishable from the orange colour of the control. On the other hand, the threshold level of detection of the SRN test in these samples was $\mathbf{0 . 1}$ ppm.

Since the presence in the urine of blood, bilirubin,

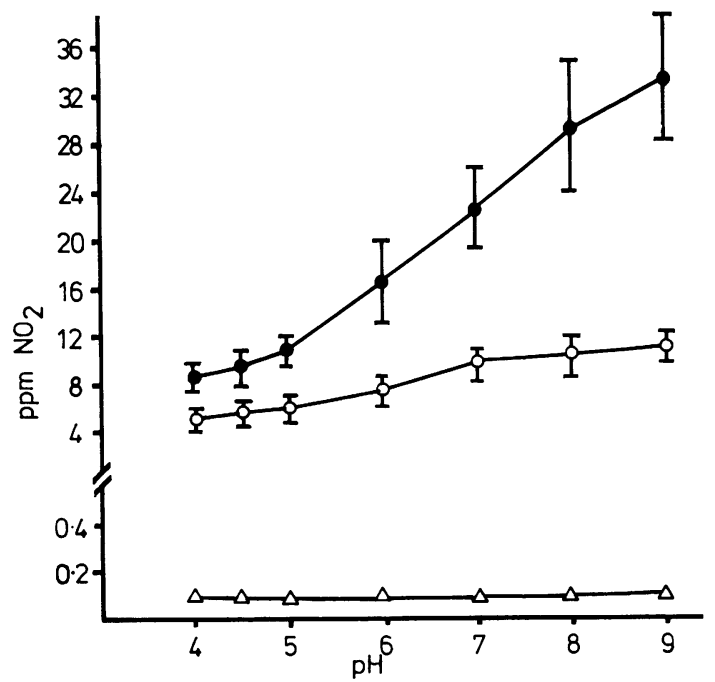

Fig. 1 Effect of $\mathrm{pH}$ in light-and dark-coloured urine on the limit of detection of Microstix and SRN tests. $\triangle-\triangle S R N$ test in light and dark urine; $\bigcirc-\bigcirc$ Microstix test in light urine; -1 Microstix test in dark urine. an abnormally high concentration of urobilinoger or a high concentration of ascorbic acid, has been reported to interfere with the Microstix ${ }^{142627}$ oxp other nitrite tests, ${ }^{22}$ we examined the effect of these factors on the SRN test. In nitrite-free urine specto mens with abnormally high urobilinogen concentras tion (4-12 mg/dl), bilirubin, macroscopic haematuria or ascorbic acid $(10-100 \mathrm{mg} / \mathrm{dl})$ the detection limit op the SRN test was not affected and remained 0.9 ppm of nitrite.

The effect of $\mathrm{pH}$ of the urine on both nitrite tests was also determined (Fig. 1). It was found that the sensitivity of the SRN test was not affected by the $p \vec{H}$ of the urine, for both dark and light urine samples On the other hand, the sensitivity of the Microsti test decreased significantly as the $\mathrm{pH}$ of the urine increased. Furthermore, for the Microstix test interference of $\mathrm{pH}$ appears to be potentiated by the colour of the urine, the influence of the $\mathrm{pH}$ being greater in the darker samples.

In some bacteriuric specimens, a combinatio between various interfering factors such as $\mathrm{pF}$. colour of the urine and other unidentified interfering factors may have given rise to a further suppression of the detection ability of the Microstix test. FQb example, the Microstix test failed to detect coñ centrations of nitrites as high as $\mathbf{2 0 , 4 0}$ and even 100 ppm as detected by the SRN test. On the other hanf, full recovery of 10,20 , and $40 \mathrm{ppm}$ of addition\&il nitrites added to these urine specimens was obtained with the SRN test.

As the SRN test gives quantitative results, it cain be used as a measure of the size of the bacterif population. The relation between the nitrite con centration, as estimated by the SRN test, and the size of the bacterial population in randomly collected 


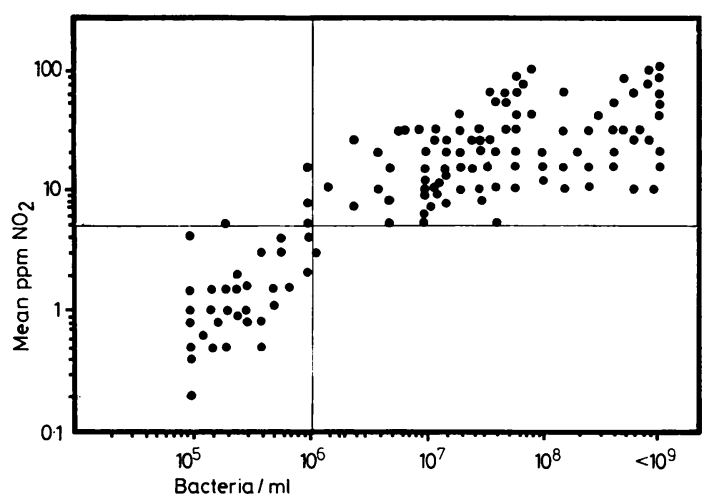

Fig. 2 Relation between nitrite concentration and the size of the bacterial population in randomly collected bacteriuric specimens.

bacteriuric specimens is presented in Fig. 2. Although there is some scattering of nitrite concentrations within each range and some overlapping between adjoining ranges, it can be seen that between $10^{5}$ and $10^{7}$ bacteria $/ \mathrm{ml}$, nitrite concentrations clearly rise with increased bacterial concentrations. At higher bacterial concentrations, this trend moderates. However, in terms of nitrite concentration, two main ranges can be distinguished: a lower range of $\leqslant 5$ ppm nitrite, which corresponds to a bacterial concentration of $10^{5}$ to $10^{6} / \mathrm{ml}$, and an upper range of $>5 \mathrm{ppm}$ (mostly 10 to $50 \mathrm{ppm}$ ) nitrite, which corresponds to $>10^{6}$ bacteria $/ \mathrm{ml}$.

Since urinary nitrate is a prerequisite for bacterial nitrate reductase, its concentration may affect the quantitative accuracy of the correlation between bacterial concentration and nitrite production. Thus, a quantitative determination of urinary nitrate in the bacteriuric specimens was carried out. The results are presented in Fig. 3. In addition, the values of nitrate plus nitrite are given, since this combined figure provides an indication of the initial concentration of nitrate before its reduction to nitrite.

It can be seen that in urine specimens with $10^{5}$ to $10^{6}$ bacteria/ml the frequency distribution of nitrate values appears to be almost identical to that of nitrate and nitrite values (Fig. $3 a, b$ ). Indeed, in these specimens, only a small part of the urinary nitrate was reduced, as expressed by the production of 0.2 to $5 \mathrm{ppm}$ of nitrites (Fig. 2). In urine specimens with higher bacterial concentrations more nitrate is reduced to nitrite (Fig. $3 \mathrm{c}-\mathrm{f}$ ). This trend is parecularly evident for samples with a bacterial concentration of $\geqslant 10^{7} / \mathrm{ml}$, in which the nitrate is largely or even completely consumed in most cases.

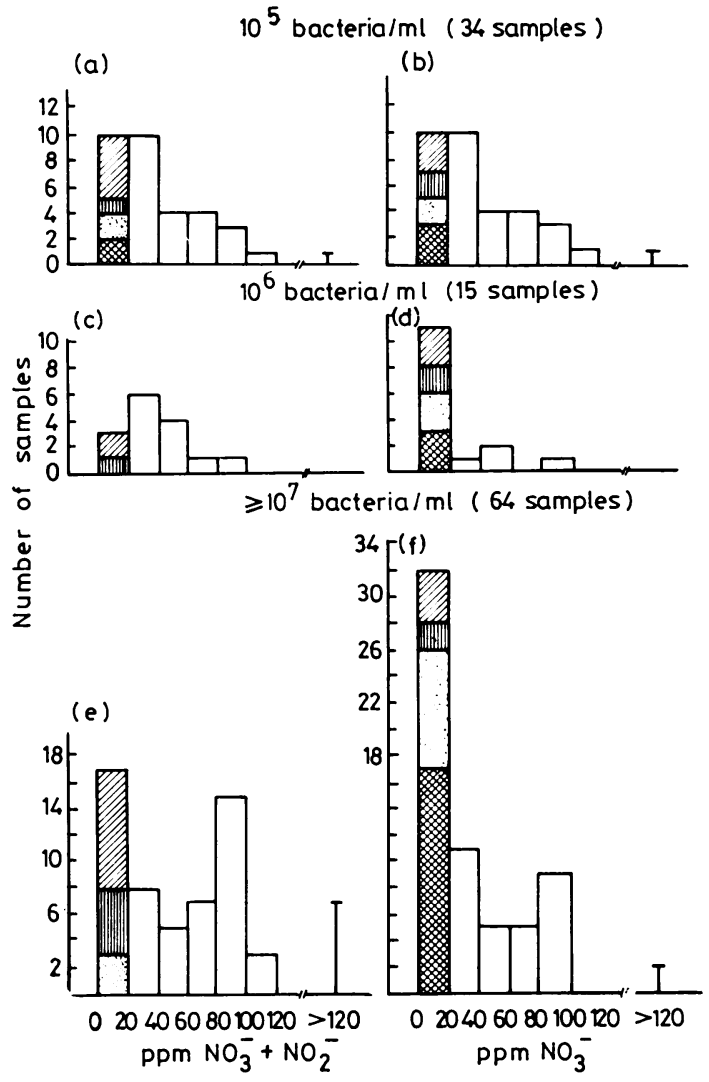

Fig. 3 Nitrate and nitrate + nitrite concentrations in randomly collected bacteriuric urine specimens. Crosshatching $=<0 \cdot 1 \mathrm{ppm} ;$ dots $=0.1-5 \mathrm{ppm} ;$ vertical stripes $=5-10$ ppm; diagonal stripes $=10-20 \mathrm{ppm}$. (Bacterial concentration is given only in orders of magnitude.)

\section{Discussion}

A simple, rapid but reliable method of testing urine specimens for bacteriuria would be of great value in case finding and follow up of UTI. The nitrite-based tests would be suitable for fulfilling this demand. However, according to several authors, the currently available nitrite tests are not sufficiently reliable. ${ }^{611} 13151619-2128$ In the light of these considerations, we evaluated a new serisitive nitrite test, the SRN test, for its suitability as a reliable diagnostic tool for the detection of bacteriuria.

According to many reports, the nature of the commonly used nitrite tests imposes some limitations on their use. A prerequisite, recommended for most of the tests, is the use of first-voided morning urine, which allows a long period for nitrite to accumulate in the bladder.11 14162930 Moreover, three consecutive first-morning urine samples are preferred by 
some authors, as a means of improving the sensitivity of the tests. ${ }^{16}{ }^{31}$ In addition, for the available nitrite tests, a high concentration of nitrate-reducing bacteria $\left(\geqslant 10^{6}\right.$ bacteria $\left./ \mathrm{ml}\right)$ is generally necessary, ${ }^{303233}$ as is an adequate concentration of urinary nitrate. ${ }^{11133033}$ Finally, the sensitivity of these tests may be affected by the presence of interfering factors, such as phenazopyridine, ${ }^{11} 12$ blood, ${ }^{14}$ ascorbic acid, ${ }^{22}{ }^{26}$ urobilinogen, ${ }^{22}$ or bilirubin. ${ }^{27}$

Our results demonstrate that none of these factors can limit the use of the SRN test as a reliable technique for the detection of bacteriuria. As is shown by the results of our clinical study (Table 1), firstmorning urine samples are not a prerequisite for the SRN test. A sensitivity of $90 \%$ was obtained for this test in urine samples collected randomly throughout the day, whereas the sensitivity of the Microstix test for these samples was as low as $30 \%$. Low sensitivity for the Microstix ${ }^{619202834}$ as well as for other nitrite tests 15162132 has also been reported for tests on urine samples about which clear data (on retention time in the bladder) were not supplied. The fact that the SRN test obviates the need for first-morning urine samples is of great practical importance in screening for bacteriuria. The necessity for long retention times of the urine in the bladder is not convenient for large populations at risk for bacteriuria, such as children, pregnant women, or patients who suffer from incontinence, or for patients visiting a general practitioner.

The higher reliability of the SRN test as compared with the Microstix test can be understood in the light of its higher sensitivity (Table 4). Furthermore, the reliability of the SRN test was not affected by various factors which do interfere with the Microstix test, such as the colour of the urine (Table 4), high urinary $\mathrm{pH}$ (Fig. 3), or the presence of phenazopyridine, bilirubin, blood, or ascorbic acid ${ }^{12} 1426$ or by a combination of these factors. At all times, the detection ability of the SRN test remained unchanged.

The current assumption that a concentration of bacteria as high as $\geqslant 10^{6} / \mathrm{ml}$ would provide the nitrite tests with adequate accuracy 303233 is not borne out by our study. We did not find that $10^{6}$ bacteria/ml was the minimal effective concentration for the Microstix test, since even at higher bacterial concentrations (up to $10^{9}$ bacteria/ml) the test "missed" some of the bacteriuric cases (Table 3). This may result from an insufficient accumulation of nitrite in these randomly-collected urine specimens or from the presence in the urine of factors which interfere with the sensitivity of the test. In contrast, the SRN test was sufficiently sensitive to reveal bacteriuria in the majority of samples with $10^{5}$ bacteria/ml and in all of the specimens with higher bacterial concentrations (Table 3 ).
The limited sensitivity of the SRN test in the bacterial specimens containing $10^{5}$ bacteria/ml may: be understood in the light of our results in an experi $\overrightarrow{\bar{F}}$ mental system (data to be published). In this in vitr $\overline{8}^{+}$ system, $E$ coli $\mathrm{B}$ was grown on Luria broth ${ }^{35}$ undef anaerobic conditions which facilitate the activatio of the bacterial nitrate reductase. Similarly, in the bladder, this bacterial system is probably activate\& by the low oxygen tension of the urine. ${ }^{36}$ In the modêp system, for an initial concentration of $10^{5}$ bacteria $\$$ $\mathrm{ml}$, a minimal incubation period of $45 \mathrm{~min}$ was required to obtain 0.2 to $0.4 \mathrm{ppm}$ of nitrite, detectable్g by the SRN test. For higher bacterial concentrations. $\left(\geqslant 10^{6} / \mathrm{ml}\right)$, however, a much shorter incubatio? time is required for producing detectable concentrat tions of nitrite, since after 15 min of incubation the concentration of nitrite was far higher than the detection limit of the test.

Thus, it appears that for random bacteriurie specimens containing $10^{5}$ bacteria/ml retention in the bladder of less than 45 min might constitute a limi to the sensitivity of the SRN test. Nevertheless, for random specimens with higher bacterial concentraso tions the retention time in the bladder between tw $\overrightarrow{0}$ urinations can be much shorter without impairing the reliability of the test. It has been stressed elses where that for reliable results with the nitrite tests, high concentration of nitrate in the urine is necese sary.11 3033 The SRN test, however, obviates thi need. Urinary nitrate concentration cannot be $\vec{\delta}$ limiting factor for the SRN test, if it is used as \$ qualitative technique for detecting bacteriuria. Ever the lowest nitrate concentrations encountered in oup study were sufficient to produce nitrite concentras tions far above the sensitivity threshold of the SRT test, namely $0 \cdot 1 \mathrm{ppm}$. In only two of the $158 \mathrm{bac}$ teriuric cases in our study was there no nitrite formation, possibly as a result of the complete absence of nitrate from the urine (Fig. 3a, b).

The possibility of using the SRN test as a quantio tative technique was also examined. Our results showed good correlation between nitrite concentra tion and the size of bacterial population for the rangf of $10^{5}$ to $10^{7}$ bacteria $/ \mathrm{ml}$, although there was measure of scattering and overlapping of the nitrit尺 values (Fig. 2). For the higher range of bacteriaf concentration ( $>10^{7}$ bacteria $\left./ \mathrm{ml}\right)$, the correlation between the two variants was poor. The lack of exact correlation may reflect at least two non-controllable factors in this random system: (a) varying retention times of the urine in the bladders of patients from whom the specimens were collected (b) varyin urinary nitrate concentrations, which depend largel on the intake of nitrate-containing foods. ${ }^{37}$

It seems that while at lower bacterial concentra? tions the crucial factor affecting the scattering an $\phi$ 
overlapping phenomena is the retention time of the urine in the bladder, at higher bacterial concentrations both the retention time in the bladder and the concentration of nitrate in the urine contribute to the lack of exact correlation. Thus, for the SRN test to serve as a quantitative technique for the detection of bacteriuria, the time of retention of the urine in the bladder and the urinary nitrate levels must be taken into consideration. However, the SRN test can be used as highly reliable qualitative technique for the detection of nitrate-reducing bacteriuria.

I would like to thank Mr E Szekely for his helpful advice, Dr C Simo for supplying the samples and her co-operation and guidance, and Ms L Uziel for her invaluable technical assistance.

\section{References}

1 Sonnenwirth AC. Collection and culture of specimens and guides for bacterial identification. In: Frankel S, Reitman SR, Sonnenwirth AC, eds. Gradwol's clinical laboratory methods and diagnosis. Vol II, 7th ed. St Louis: CV Mosby Co, 1970:1136.

${ }^{2}$ Norden CW, Kass EH. Bacteriuria of pregnancy-a critical appraisal. Annu Rev Med 1968;19:431-71.

${ }^{3}$ Naeye RL. Causes of the excessive rates of perinatal mortality and prematurity in pregnancies complicated by maternal urinary tract infections. N Engl J Med 1979; 300:819-23.

4 Forland M,Thomas V, Shelokov A. Urinary tract infections in patients with diabetes mellitus. JAMA 1977;238:19246.

${ }^{5}$ Ormonde NWH, McCaann VJ, Calder JS, Goodwin CS, David RE, Nicol DJ. Urinary tract infections in patients with diabetes mellitus. Aust NZ J Med 1979;9:101-2.

- Marr TJ, Traisman HS. Detection of bacteriuria in pediatric outpatients. A new culture device. Am J Dis Child 1975;129:940-3.

${ }^{7}$ Edelmann CM, Ogwo JE, Fine BP. Prevalence of bacteriuria in full-term and premature newborn infants. $J$ Pediatr 1973;82:125-9.

${ }^{8}$ Andriole VT. Care of the indwelling catheter. In: Kaye D, ed. Urinary tract infection and its management. St Louis: CV Mosby Co, 1972:256-66.

- Guttman D, Naylor GRE. Dip-slide: an aid to quantitative culture in general practice. Br Med J 1967;iii:343-5.

10 Cohen SN, Kass EH. A simple method for quantitative urine culture. $N$ Engl J Med 1967;277:176-80.

11 Craig WA, Kunin CM, De Groot J. Evaluation of new urinary tract infection screening devices. Appl Microbiol 1973;26:196-201.

12 Mofatt CM, Britt MR, Burke JP. Evaluation of miniature test for bacteriuria using dehydrated media and nitrate pads. Appl Microbiol 1974;28:95-9.

13 Lie JT. Evaluation of a nitrite test kit (Stat-test) for the detection of significant bacteriuria. J Clin Pathol 1968; 21 :443-4.

${ }^{14}$ Kunin CM, De Groot JE. Self-screening for significant bacteriuria. Evaluation of dip strip combination nitrite/ culture test. JAMA 1975;231:1349-53.

${ }^{15}$ Skelton IJ, Hogan MM, Stokes B, Hurst JA. Urinary tract infections in childhood. The place of the nitrite test. Med $J$ Aust $1977 ; 1: 882-6$.
${ }^{16}$ Guingnard JP, Torrado A. Nitrite indicator strip test for bacteriuria. Lancet $1978 ;$ i:47.

${ }^{17}$ Kunin CM. Detection, prevention and management of urinary tract infections. Philadelphia: Lea \& Febiger, 1973:86-141.

18 Pacova Z, Kocur M. A comparison of tests for nitrate reduction. Zentralblatt fuer Bakteriologie Parasitenkunde, Infektions, Krankheiten und Hygiene, Abteilung 1, Originale A 1975;231:525-34.

19 St George J, Osoba AO. Evaluation of Microstix as a screening procedure for bacteriuria of pregnancy in tropical countries. Niger Med J 1977;7:177-83.

${ }^{20}$ Hamilton-Miller JMT, Brooks SJD, Brumfitt W, Bakhtiar M. Screening for bacteriuria: Microstix and Dipslides. Postgrad Med J 1978;53:248-50.

${ }^{21}$ Sinaniotis CA, Haratsaris MN, Papadatos CJ. Nitrite indicator strip test for bacteriuria. Lancet 1978 ; i:776-7.

22 James GP, Paul KL, Fuller JB. Urinary nitrite and urinary tract infection. Am J Clin Pathol 1978;70:671-8.

${ }^{23} \mathrm{~K}$ ass EH. Pyelonephritis and bacteriuria. A major problem in preventive medicine. Ann Intern Med 1962;56:45-53.

24 Peduta E, Jordan RC. Evaluation of the Szechrome method for the determination of nitrate. Research Triangle Park, NC 27709: Northrop Services, 1976.

${ }^{25}$ Kahler RL, Guze LB. Evaluation of the Griess nitrite test as a method for the recognition of urinary tract infection. J Lab Clin Med 1957;49:934-7.

26 George RC, Ponzo JL. An improved quantitative method for urine nitrite. Clin Chem 1979;25:1092.

27 Ames Comp. Microstix 3. Stoke Poges, England: 1979.

${ }^{28}$ Duerden BI, Moyes A. Comparison of laboratory methods in the diagnosis of urinary tract infection. J Clin Pathol 1976;29:286-91.

${ }^{29}$ Czerwinski AW, Wilkerson RG, Merril JA, Braden B, Colmore JP. Evaluation of first morning urine to detect significant bacteriuria. Am J Obstet Gynecol 1971;110: 42-5.

${ }^{30}$ Scheifele DW, Smith AL. Home testing for recurrent bacteriuria using nitrite strips. Am J Dis Child 1978;132: 46-8.

${ }^{31}$ Kunin CM, De Groot JE, Uehling D, Ramgopal V. Detection of urinary tract infections in 3 to 5 year old girls by mothers using a nitrite indicator strip. Pediatrics 1976;57:829-35.

${ }^{32}$ Kincaid-Smith P, Bullen M, Mills J, Fussel U, Huston N. The reliability of screening tests for bacteriuria in pregnancy. Lancet 1964 ;ii:61-2.

${ }^{33}$ Czerwinski AW, Wilkerson RG, Merril JA, Braden B, Colmore JP. Further evaluation of the Griess test to detect significant bacteriuria. Am J Obstet Gynecol 1971; 110:677-81.

34 Winter CHC. Rapid miniaturized tests for bacteriuria: Microstix and bacturcult urine tests. J Urol 1975;114: 755-7.

${ }^{35}$ Miller JH. Experiments in molecular genetics. Cold Spring Harbor Laboratory 1972:433.

${ }^{36}$ Wirz H, Dirix R. Urinary concentration and dilution. In: Orloff J, Berlinger RW, Geiger SR, eds. Handbook of physiology. Section 8. Renal physiology. Washington DC: Annals of the Physiology Society, 1973:423.

${ }^{37}$ Radomski JL, Palmiri C, Hearn WL. Concentrations of nitrate in normal human urine and effect of nitrate ingestion. Toxicol Appl Pharmacol 1978;45:63-8.

Requests for reprints to: Dr T Rabi, Division of Natural Products, Research and Development Authority, BenGurion University of the Negev, Beer-Sheva, Israel. 